\title{
Entrepreneurial Opportunity And Collaborative Research Efforts As Panaceas For Improving Academic Entrepreneurship Among Ekiti State University Staff
}

\author{
Ayodeji. M. Awolaja, (Ph.D) \\ Department of Business Administration, \\ Faculty of Management Sciences, \\ Ekiti State University Ado Ekiti.
}

\begin{abstract}
The study assessed the impact of entrepreneurial opportunity and collaborative research efforts on academic entrepreneurship among Ekiti State University Staff. The study made use of prior entrepreneurial opportunity and collaborative research efforts as independent variables. The period of study was between 2017-2018. Descriptive survey research design was adopted and the research sample size of $\mathbf{1 0 0}$ was drawn from the total population of academic staff in all faculties in Ekiti State University through the adoption of Taro Yamane (1967) model. Convenience and purposive sampling techniques were adopted to select the sample that shares the same characteristics in order to ensure that every member of staff of all faculties was represented. Data were analysed using both descriptive and inferential statistics. The study revealed that entrepreneurial opportunity exerts positive impact on academic entrepreneurship among Ekiti state university staff and also, that collaborative research efforts exert positive impact on academic entrepreneurship among Ekiti state university staff.
\end{abstract}

Keywords: Entrepreneurial opportunities, collaborative research efforts, and academic entrepreneurship

\section{INTRODUCTION}

Entrepreneurship is considered to be a core competence for growth, employment and personal fulfillment (Yildirim\&Askun, 2012). Higher education institutions play a fundamental role in establishingand developing an entrepreneurship-oriented economy as these institutions represent a main source of new knowledgeand hold a constantly regenerating stock of students and scientists (Lautenschlager\&Haase, 2011). Roles ofuniversities in economic growth through contributing to creation of entrepreneurship climate in a country haveevolved in time and grew beyond being just educators and disseminating the existing knowledge. Universitiesnaturally generate new ideas, to contribute to innovation by creating knowledge and developing technology as anoutput of their research activities. However, today, to overcome the challenges that the financial crisis brought, missionof universities evolved beyond their traditional roles.

Academic entrepreneurship has started to be considered a third mission in which university institutions engage, in addition to the traditional mandates of teaching and research. To encourage entrepreneurship among academics and students, universities are now developing entrepreneurship polices and implementing these initiatives to embed entrepreneurial thinking and practices within teaching, research and administration. (Nyeko, \& Sing, 2015).

This phenomenon has been described as the academic revolution (Ahmad, Halim, Ramiyah, \& Rahman, 2013), and has resulted in the emergence of various types of universities, such as, research universities, technological universities, teaching universities, hybrid universities and 
of late, entrepreneurial universities. In a university setting, academic entrepreneurship is the synthesis and integration of scientific, academic and commercial activities (Sporn, 2001). It is often characterised by formal arrangements to commercialise academic intellectual property through knowledge (e.g. consulting or contract research), transfer of technology (e.g. patent or licensing) and transfer of products or services (e.g. spin-offs) (Radosevich,1995). According to Tijesin (2006), Academic entrepreneurship occurs at the level of individuals or groups of individuals acting independently or as part of faculty or university systems, who create new organizations, or instigate innovation within or outside the university.

However there is still a significant need for up-to-date and multidimensional research and studies about the entrepreneurial opportunities and advantages inherent in collaborative academic efforts, intentions, activities and contributions of universities to economic growth in developing countries.

\section{Entrpreneurial Opportunity}

\section{CONCEPTUAL CLARIFICATION}

Shane and Venkataraman (2000) define entrepreneurial opportunities as those situations in which new goods, services, raw materials, and organizing methods can be introduced and sold at greater than their cost of production.' These opportunities are treated as objective phenomena, though their existence is not known by all agents. Opportunity is a central concept within the entrepreneurship field and there is now a critical mass of literature centered on this concept. Its identification constitutes an interesting step for any business creation (Gaglio\& Katz, 2001). Beside the opportunities identification, access to external financing is very useful for the exploitation of these opportunities and for developing new products.

For a better clarification, the concept of Entrepreneurial Opportunity and Development were viewed from two dimensions: Prior entrepreneurial opportunities and collaborative research efforts.

\section{Prior Entrepreneurial Opportunities}

Entrepreneurship research highlights that prior entrepreneurial experience increases the probability of identification and exploitation of entrepreneurial opportunities since it helps to develop the skills necessary to undertake such functions (Shane \&Venkataraman 2000, and Shane 2000). For instance, Wright, Birley, \& Mosey(2004) pointed to increasing evidence of the phenomenon of recurrent academic entrepreneurs, that is, researchers who undertake multiple entrepreneurial ventures. Similarly, Bercovitz\& Feldman (2008) revealed that academic researchers who have disclosed inventions to their university technology transfer offices in the past are likely to repeat this behavior. Prior experience in identifying entrepreneurial opportunities is likely to increase a researcher's perception of the commercial potential of his/her current research activities.

\section{Collaborative Research}

Experience of working with industry, for example, has often been identified in the universityindustry linkages literature as a good predictor of effective technology transfer. For instance, the study conducted by Landry, Amara and Ouimet (2007) shows that the relational capital of academic researchers with users (e.g. managers in firms and industrial associations) is positively and significantly associated with the extent to which the academic researcher engages in knowledge transfer activities. At the organisational level, Feldman \&Desrochers (2004) and Jong (2006) found that universities and departments with an established tradition in collaborative research with firms, are more likely to recognise the commercial opportunities of their research activities. Along the same lines, Ponomariov\& Boardman (2008) posit that 
fostering informal links between university and industry favours later collaboration. Indeed, collaboration with industry on the one hand, and awareness and ability to exploit commercial opportunities are likely to be self-reinforcing.

\section{ACADEMIC ENTREPRENEURSHIP}

The common definition of academic entrepreneur is similar to the original definition of entrepreneur. It states that academic entrepreneur is a university scientist, most often a professor, sometimes a PhD student or a post-doc researcher, who sets up a business company in order to commercialize the results of his/her research. Academic entrepreneurship today can be understood as either:

(i) A knowledge-based profession that is centered on technological development

(ii) An income-oriented activity that creates a small business or firm from said technological development

(iii) A particular behavior to be adapted by researchers in order to modify the pattern of university research.

\section{Academic Entrepreneur vs. Entrepreneur}

A key distinction between the academic field of entrepreneurship and other entrepreneurial professions is that often small businesses tend to focus on societal impact and proliferation of their product, while researchers and the products that they market also aid in the progression and of the academic field. Many, if not most, academic entrepreneurs are also linked in some way to their university, faculty members, and students with both formal and informal obligations, which can create certain constraints and opportunities for researchers, while entrepreneurial businesses don't hold such connections.

\section{Figure 1. Proposed framework of opportunity recognition}

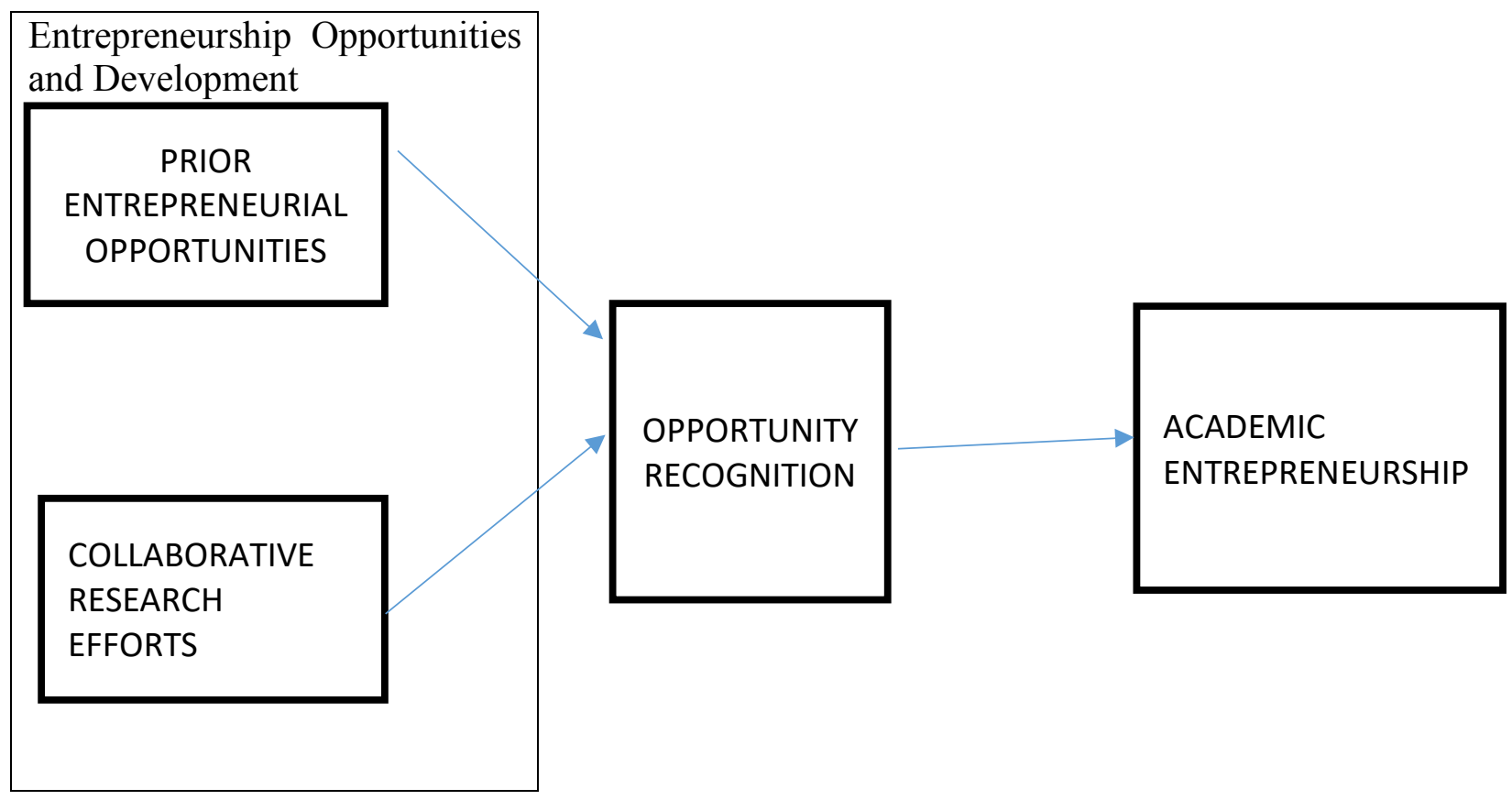

\section{Theoretical Framework}

\section{Economic Entrepreneurship Theories}

The economic entrepreneurship theory has deep roots in the classical and neoclassical theories of economics, and the Austrian market process (AMP). These theories explore the economic factors that enhance entrepreneurial behavior. While the classical theory extolled the virtues of 
free trade, specialization, and competition (Ricardo, 1817; Smith, 1776), the neo-classical model emerged from the criticisms of the classical model and indicated that economic phenomena could be relegated to instances of pure exchange, reflect an optimal ratio, and transpire in an economic system that was basically closed and the Austrian Market Process (AMP) focused on unanswered questions of the neo-classical movement and this led to a new movement which became known asthe Austrian Market process (AMP). The AMP, a model influenced by Joseph Aloi Schumpeter (1934) concentrated on human action in the context of an economy of knowledge

\section{METHODS}

The research design utilized for the purpose of this study is descriptive research survey design. The data were collected through questionnaires that were administered to selected respondents. This is because the variables of interest for the measurement are purely qualitative which lend themselves to description. The population comprised of 14,664, being the entire academic staff in Ekiti State University, Ado-Ekiti, Ekiti state, Nigeria.The researcher made use of convenience and purposive sampling techniques to arrive at 15 respondents from each faculty; these respondents were chosen because they were the easiest to obtain for the study. Therefore, the research sample size was 100through the adoption of Taro Yamane (1967) model. This study made use of primary data collection because it allowed the respondents enough time to think and provide answers to questions.

\section{RESULTS AND INTERPRETATION}

Table 1.1: Correlation Matrix

\begin{tabular}{|c|c|c|c|}
\hline & AE & PEO & CRE \\
\hline AE & 1 & & \\
\hline PEO & 0.814945 & 1 & \\
\hline CRE & 0.807435 & 0.831044 & 1 \\
\hline
\end{tabular}

Table 1.1 presents correlation coefficient for pairs of variables used in the study. Specifically the table reported correlation statistics of $0.814945,0.807435,0.831044$, for AE, CRE, and PEO respectively. The result revealed that there is positive relationship between the variables used in the study. Notably the result showed that academic entrepreneurship among Ekiti state university staff has increased over the years alongside increase in entrepreneurial opportunities and collaborative research efforts. This gives a reflection of the interconnection between pairs of variables included in the model of the study.

Table 1.2: Regression Estimation Result

Dependent Variable: AE

\begin{tabular}{|c|r|r|r|r|}
\hline Variable & Coefficient & \multicolumn{1}{|l|}{ Std Error } & \multicolumn{1}{|c|}{ t-statistics } & \multicolumn{1}{l|}{ Prob. } \\
\hline C & 1.727841 & 1.817055 & 0.950902 & 0.3558 \\
\hline PEO & 0.130345 & 0.124834 & 1.044150 & 0.3119 \\
\hline CRE & 0.066068 & 0.155849 & 0.423925 & 0.6773 \\
\hline
\end{tabular}

R-Squared $=0.920875 ; \quad$ Adjusted $\quad$ R-Square $=0.906039 ; \quad$ F-statistics $=62.07020 ; \quad$ Prob(F-statistics $)=$ 0.000000

Result of the regression estimation presented in table 1.2 revealed coefficient estimates of $0.130345,0.066068$, alongside probability values of $0.3119,0.6773$, for prior entrepreneurial opportunities and collaborative academic efforts respectively. The result revealed that all the explanatory variables exert positive impact on academic entrepreneurship. In specific term the result showed that academic entrepreneurship will increase by about 0.130345 for every unit 
increase in prior entrepreneurial opportunities. The increase in academic entrepreneurship for every unit increase in collaborative academic efforts stood at 0.66068 . The corresponding probability values presented in table4.2 showed that prior entrepreneurial opportunities and collaborative academic efforts on academic entrepreneurship tend to be significant. R-square statistics reported in table 1.2 stood at 0.920875 , which implies that about $92.0 \%$ of the systematic variation in academic entrepreneurship can be explained by joint variation in prior entrepreneurial opportunities and collaborative academic efforts. F-statistics and probability values reported in table 4.2 reflect that the model is a good fit, with the probability value of the reported statistics less than 0.05 .

\section{DISCUSSION OF FINDINGS}

The study discovered that prior entrepreneurial opportunities exert positive impact on academic entrepreneurship among Ekiti state university staff which implies that earlier entrepreneurial exposures of researchers often lead to a positive influence in academic entrepreneurship. The level of prior entrepreneurial opportunities will determine improvement on academic entrepreneurship which will be favorable to the economy and the educational system on the long run. The study discovered that collaborative research efforts exert positive impact on academic entrepreneurship among Ekiti state university staff which implies that increase in academic entrepreneurship could result based on collaborative research efforts of intellectuals from within the industries and academics.

\section{CONCLUSION AND RECOMMENDATIONS}

This study assessed impact of prior entrepreneurial opportunities and collaborative academic efforts on academic entrepreneurship. Prior entrepreneurial opportunities were found to have positive impact on academic entrepreneurship and collaborative academic efforts were found to be positively impacted on academic entrepreneurship. By these, it is thus concluded that prior entrepreneurial opportunities and collaborative academic efforts are both means of improving on entrepreneurial base of institutions and the nation. Meanwhile, vocational centers should be strengthened and expanded where staff can be apprenticed to, since entrepreneurship education offers no specific vocational skill. Also, there is a need to ensure that entrepreneurship curriculum contents in Nigerian universities motivate entrepreneurial actions and real life simulations of the process of entrepreneurship. Further studies can be carried out on other dimensions of entrepreneurial opportunities and development like external academic research networks, integration of multi-disciplinary research and quality of academic research.

\section{References:}

Acs, Z. J., \&Audretsch, D. B. (1988). Innovation in large and small firms: An empirical analysis. American Economic Review, 78, 678-690.

Agrawal, A., \& Henderson, R. (2002). Putting patents in context: Exploring knowledge transfer from MIT. Management Science, 48(1), 44-60.

Aldrich, H. E. (1999). Organisations Evolving. Sage Publications.

Aldrich, H. E., \& Cliff, J. (2003). The pervasive effects of family on entrepreneurship: toward a family embededness perspective. Journal of Business Venturing, 18, 573-596.

Aldrich, H. E., Rosen, B., \& Woodward, W. (1987). The impact of social networks on business founding and profit. Frontiers of Entrepreneurship Research. Babson College, Wellesley, MA.

Alvarez, S., \&Busenitz, L. (2001). The entrepreneurship of resource based theory. Journal of Management, 27,755775.

Amaeshi, U.F (2005). Entrepreneurship, Enugu. Publishers Ltd. 
Anderson, A., \& Miller, C. (2003). Class matters: human and social capital in the entrepreneurial process. The Journal of Socio-Economics, 32, 17-36.

Anis, O., \& Mohamed, F. (2012). How entrepreneurs identify opportunities and access to external financing in Tunicia's micro-enterprise. African Journal of Business Management, 6(12), 4635-4647.

Ardichvili, A., Richard, C., \&Sourav, R. (2003). A theory of entrepreneurial opportunity identification and development. Journal of Business Venturing, 18(1), 105-123.

Arenius, P, De Clercq, D., \& De Clercq, D. (2005). A network-based approach on opportunity Recognition. Small Business Economics, 24(3), 249-265.

Bammer, G. (2008). Enhancing research collaborations: Three key management challenges. Research Policy, 37(5), 875-887.

Baskerville, R.F. (2003). Hofstede Never Studied Culture. Accounting, Organizations and Society, 28(1), 1-14.

Baum, J.R., Edwin, A.L., \& Ken, G.S. (2001). A multi-dimensional model of venture growth. Academy of Management Journal, 44, 1-25.

Becker (1975). Human Capital. Chicago, IL: Chicago University Press.

Begley, T.M., \& Boyd, D.P. (1987). Psychological characteristics associated with performance in entrepreneurial firms and smaller businesses. Journal of Business Venturing, 2, 79-93.

Bercovitz, J., \& Feldman, M. (2008). Academic entrepreneurs: Organizational change at the individual level. Organization Science, 19(1), 69-89.

Bilic, A., Prka, G., \&Vidovic. (2011). How does education influence entrepreneurship orientation? Management,16(1), 115-128.

Blanchflower, D., Oswald, A., \&Stutzer, A. (2001). Latent entrepreneurship across nations? European Economic Review, 45,680-691.

Bonnett, C., \&Furnham, A. (1991). Who wants to be an entrepreneur? A study of Adolescents interested in a Young Enterprise scheme. Journal of Economic Psychology, 12, 465-78.

Brockhaus, R.H. (1980). Risk taking propensity of entrepreneurs. Academyof Management Journal, 23, 509-520.

Burt, R. S. (1992).The social structure of competition, networks and organizations: Structure, form, and action. 57-91.

Busenitz, L.W. (1996). Research on entrepreneurial alertness. Journal of Small Business Management, 34(4), 35-44.

Busenitz, L.W., \& Jay. B.B. (1997). Differences between entrepreneurs and managers in large organizations: Biases and heuristics decision-making. Journal of Business Venturing, 12(1), 9-30.

Chandler, G., \& Hanks, S. (1998). An examination of the substitutability of founder's human and financial capital in emerging business ventures.Journal of Business Venturing, 13, 353-369.

Clausen, T.H. (2006). Who identifies and Exploits entrepreneurial opportunities. Retrieved from www.ccsr.ac.uk

Coleman, J.S. (1998). Social capital in the creation of human capital. The American jounral of sociology, 94, 95-120.

Coon, D. (2004). Introduction to Psychology (9th Ed). Minneapolis: West Publishing Company.

Cooper, A., Woo, C., \& Dunkelberg, W. (1988). Entrepreneurs' perceived chances for success. Journal of Business Venturing, 3, 317-332.

Cromie, S. (2000). Assessing entrepreneurial inclination: Some approaches empirical evidence. European Journal of Work and Organizational Psychology, 9(1), 7-30.

D'este,P., Mahdi, S., \& Neely, A. (2009). Academic entrepreneurship: What re the factor shaping the capacity of academic researchers to identify and exploit entrepreneurial opportunity. Proceedings of the summer conference of CBS, Fedriksberg, Denmark.

Davidson, P., \& Honing, B. (2003). The role of social and human capital among nascent entrepreneurs. Journal of Business Venturing, 20,121.

Davidson, P., \& Honing, B. (2003). The role of social and human capital among nascent entrepreneurs. Journal of Business Venturing, 20,121.

Davidsson, P., \& Benson, H. (2003). The role of social and human capital among nascent entrepreneurs. Journal of Business Venturing, 18(3), 301-331. 
Deeds, D. L., Decarolis, D., \& Coombs, J.E. (1997). The impact of firm specific capabilities on the amount of capital raised in an initial public offering: Evidence from the biotechnology industry. Journal of Business Venturing, 12(1), $31-46$

Donald, S.S., \& Wright, M. (2015). Academic entrepreneurship: Time for a rethink. ERC Research Paper, 32.

Drucker, P.F. (1985).Innovation and Entrepreneurship. New York: Harper \& Row Publishers.

Eisenhauer, J.G. (1995). The entrepreneurial decision: Economic theory and empirical evidence. Entrepreneurship theory \& practice. Retrieved from www.allbusiness.com

Etzkowitz, H. (1989). Entrepreneurial science in the academy - a case of the transformation of norms. Social Problems, 36(1), 14-29.

Evans, D., \&Jovanovic, B. (1989). An estimated model of entrepreneurial choice under liquidity constraints. The Journal of Political Economy, 97, 808-827.

Evans, D., \&Jovanovic, B. (1989). An estimated model of entrepreneurial choice under liquidity constraints. The Journal of Political Economy, 97, 808-827.

Feldman, M., \&Desrochers, P. (2004). Truth for its own sake: Academic culture and technology transfer at Johns Hopkins University. Minerva, 42, 105-126.

Fiet, J.O. (2002). The Systematic Search for Entrepreneurial Discoveries, Westport, CT: Quorum Books.

Franzoni, C., \&Lissoni, F. (2007). Academic entrepreneurs: Critical issues and lessons from Europe. Paper presented ESSID, the European Summer School of Industrial Economics, held in Corsica, September 2005.

Gaglio, C.M., \& Katz, J.A. (2001). The psychological basis of opportunity identification: Entrepreneurial alertness. Small Business Economics, 16(2).

Gaglio, C.M., \& Katz, J.A. (2001). The psychological basis of opportunity identification: Entrepreneurial alertness. Small Business Economics, 16(2).

Gartner, W.B., Shaver, K.G., Carter, N.M., \& Reynolds, P.D. (2004). Handbook of entrepreneurial dynamics. Thousand Oaks, CA: Sage Publications.

Granovetter, M. (1973). The Strength of Weak Ties. American Journal of Sociology, 78(6), 1360-1380.

Granovetter, M. (1983). The strength of weak ties: A network of theory revisited. Sociological Theory 1, 201-233.

Haynie, J.M., Dean, A.S., \& Jeffrey, S.M. (2009). An opportunity for me? The role of resources in opportunity evaluation decisions. Journal of Management Studies, 46, 337-361.

Hills, G.E., Lumpkin, G.T., \& Singh, R.P. (1997). Opportunity recognition: Perceptions and behaviours of entrepreneurs. Frontiers of Entrepreneurship Research. Babson College, wellesley, MA.

Ho, T.S., \&Koh, H.C. (1992). Differences in psychological characteristics between entrepreneurially inclined and non-entrepreneurially inclined accounting graduates in Singapore. Entrepreneurship, Innovation and Change: An International Journal, 1, 43-54.

Hurst, E., \&Lusardi, A. (2004). Liquidity constraints, household wealth, entrepreneurship, Journal of Political Economy, 2,112.

Johnson, B. (1990). Toward a multidimensional model of entrepreneurship: The case of achievement and the entrepreneur. Entrepreneurship: Theory \& Practice, 14, 39-54.

Kaish, S., \& Benjamin, G. (1991). Characteristics of opportunities search of entrepreneurs versus executives: Sources, interests, general alertness. Journal of Business Venturing, 6(1) 45-61.

Kauffman, S. (2008). Reinventing the sacred. New York: Persesus Publishing.

Kickul, J., \& Walters, J. (2002). Recognizing new opportunities and innovations: The role of strategic orientation and proactivity in internet firms. International Journal of Entrepreneurial Behavior and Research, 8(6), 292-308.

Kim, P., Aldrich, H.E., \&Keister, L.A. (2003). Access (not) denied: The impact of financial, human and cultural capital on becoming a nascent entrepreneur. Working paper.

Kirzner, I.M. (1973). Competition and Entrepreneurship. Chicago, IL: University of Chicago.

Kirzner, I.M. (1999). Creativity and or alertness: A reconsideration of the Schumpeterian entrepreneur. Review of Austrian Economics, 11. 
Klien, P.G. (2008). Opportunity discovery, entrepreneurial action, and economic organisation. Strategic Entrepreneurship Journal, 2, 175-190.

Knight, F.H. (1921). Risk, uncertainty, and profit. Library of Economics and Liberty. Retrieved from www.econlib.org/library/Knight/knRUP1.html

Koh, H.C. (1996). Testing hypotheses of entrepreneurial characteristics: A study of Hong Kong MBA students, Journal of Managerial Psychology, 11, 12-25.

Korunka, C., Frank, H., Lueger, M., \&Mugler, J. (2003). The entrepreneurial personality in the context of resources, environment, and the startup process -A configurational approach. Entrepreneurship Theory and Practice, 28(1), 23-42.

Kuratko, D.F. (2005). The emergence of entrepreneurship education: Development, trends and challenges. Entrepreneurship Theory andPractice,29(5), 577-597.

Landry R., Amara N., \&Ouimet, M. (2007). Determinants of knowledge transfer: Evidence from the Canadian university researchers in natural sciences and engineering. Journal of Technology Transfer, 32, 561-592.

Landstrom, H. (1998). The Roots of Entrepreneurship Research. Conference proceedings, Lyon, France, November 26-27.

Landstrom, H. (1998).The Roots of Entrepreneurship Research, Conference proceedings, Lyon, France, November 26-27.

Lim, W.L., \& Xavier, S.R. (2015). Opportunity recognition framework: Exploring technology entrepreneurs. American Journal of Economics, 5(2), 105-111.

Lin, X., \& Qin, K. (2011). Embeddedness, social network theory and social capital theory: Antecedents and consequence. Management and Service Science.

Louis, K.S, Blumenthal, D., Gluck, M.E., \&Stoto, M.A. (1989). Entrepreneurs in academe: An exploration of behaviours among Life scientists. Administrative Science Quarterly, 34(1), 110-131.

McClelland, D.C. (1961).The Achieving Society, N.J: Van Nostrand, Princeton.

McOliver, F.O. (1998). Business Enterprises (How to start and succeed). Benin City: Uniben Press.

Meyer, M. (2006). Are patenting scientists the better scholars? An exploratory comparison of inventor-authors with their non-inventing peers in nano-science and technology. Research Policy, 35(10), 1646-1662.

Mitchell, R.K., Smith, J.B., Morse, E.A., Seawright, K.W., Peredo, A., \& McKenzie, B. (2002). Are Entrepreneurial cognitions universal? Assessing entrepreneurial cognitions across cultures. Entrepreneurship, Theory and Practice, 9-32.

Mohar, Y.M.S, Singh, J., \& Kishore, K. (2007). Relationship between psychological characteristics and entrepreneurial inclination: A Case Study of Students at University Tun Abdul Razak. Journal of Asia Entrepreneurship and Sustainability, 8. ProQuest Information and Learning Publishers.

Murphy, J.P., Liao, J., \&Welsch, P.H. (2006). A conceptual history of entrepreneurial thought, Journal of Management History. 12, 9-24.

Ndechukwu, F.N. (2001). Packing Small and Medium Scale Industries for Equity Investment, at a Workshop Organize by the bankers Committee for Small and Medium Scale Enterprise

Nicolau, N., \&Birley, S. (2003). Academic networks in a trichotomous categorization of university spinouts. Journal of Business Venturing, 18(3), 333-359.

North, D.C. (1990). Institutions, Institutional Change, and Economic Performance. New York: Norton.

Nyeto, K.M., \& Sing, K.N. (2015). Academic entrepreneurs and entrepreneurial academic: Are they the same. International Journal of Social Science and Humanity, 5(12), 1050-1055.

Okpara, F.O. (2000). Entrepreneurship: Test and cases. Enugu: Precision Printers and Publishers.

Pervin, L.A. (1980). Personality: Theory, Assessment and Research. New York: John Wiley \& Sons.

Ponomariov, B., \& Boardman, P.C. (2008). The effect of informal industry contacts on the time university scientists allocate to collaborative research with industry. Journal of Technology Transfer, 33, 301-313.

Powers, J.B., \& McDougall, P.P. (2005). University start-up formation and technology licensing with firms that go public: A resource-based view of academic entrepreneurship. Journal of Business Venturing, 20(3), 291-311. 
Rafols, I. (2008). Strategies for knowledge acquisition in bionanotechnology. Why are interdisciplinary practices less widespread than expected? Innovation, 20(4), 395-412.

Rauch, A., \&Frese, M. (2000). Psychological approaches to entrepreneurial success: A general model and an overview of findings, In: Cooper C L, Robertson I T (eds.), International Review of Industrial and Organisational Psychology, 10, 1-41.

Reynolds, P.D. (1991), Sociology and entrepreneurship: concepts and contributions Entrepreneurship: Theory \& Practice, 16(2), 47-70.

Ricardo, D. (1817). On the Principles of Political Economy and Taxation. London: John Murray.

Robinson, P.B., Stimpson, D.V., Huefner, J.C., \& Hunt, H.K. (1991). An attitude approach to the prediction of entrepreneurship. Entrepreneurship Theory and Practice, 15(4), 13-32

Rotter, J. (1966). Generalized expectancies for internal versus external control reinforcements. Psychological Monographs, 80, 609.

Sambasivan, M., Mohani, A., \&Yuzliani, Y. (2009) Impact of personal qualities and management kills of entrepreneurs on venture performance in Malaysia: Opportunity recognition skills as a mediating factor. Technovation, 29(11), 798-805.

Sandsrom, C., Wennberg, K., Wallin, M.W., \&Zherlygina, Y. (2016). Public policy entrepreneurship initiatives: a review and critical discussion. Chalmers University of technology. Gothenburg; Sweden.

Santarelli, E., \&Hien, T.T. (2013). The interplay of human and social capital in shaping entrepreneurial performance: The case of Vietnam. Small Business Economics, 40(2), 435-458.

San-Velasco, S.A. (2006).Opportunity development as a learning process for entrepreneurs. School of technology Management and Economics, Chalmers University of Technology. Goteborg; Sweden. International Journal of Entrepreneurial Behaviour\& Research, 12(5), 1335-2554.

Say, J.B. (1803). Tiraitéd'économiepolitique, ou simple exposition de la manièredont se forment, se distribuent, et se composent les richesses. A.A. Renouard: Paris.

Schumpeter, J.A. (1934). The Theory of Economic Development. Cambridge, MA: Harvard University Press.

Shane, S. (2000). Prior knowledge and the discovery of entrepreneurial opportunities. Organisation Science, 11, 448-469.

Shane, S. \&Venkataraman, S. (2000). The promise of entrepreneurship as a field of research. Academy of Management Review, 25(1), 217-226.

Shane, S.A (1994). The effect of national culture on the choice between licensing and direct foreign investment. Strategic Management Journal 15,627-642.

Shane, S.A. (2003). A General Theory of Entrepreneurship: The Individual-Opportunity Nexus. Cheltenham: Edward Elgar.

Shane, S.A., \&Eckhardt, J.T. (2003). Opportunities and entrepreneurship. Journal of Management, 29 (3), 333-349.

Shaver, K.G., \& Scott, L.R. (1991). Person, process, choice: the psychology of new venture creation.

Entrepreneurship Theory \& Practice, 16, 23-45.

Singh, R.P. (1998). Entrepreneurial opportunity recognition through social networks.SMECorp. . SME Annual Report 2012/2013.

Smith, A. (1776). An inquiry into the Nature and Causes of the Wealth of Nations. London: Methuen Publishers.

Stel,V.A., Carree, M., \&Thurik, R.(2005).The effect of Entrepreneurial activity on national economic growth. Small Business Economics, 24, 311-321.

Stevenson, H., \&Harmeling, S. (1990). Entrepreneurial management's need for a more chaotic Theory. Journal of Business Venturing, 5, 1-1.

Stevenson, H.H., \&Jarillo J.C. (1990). A paradigm of entrepreneurship: Entrepreneurial management. Strategic Management Journal, 11, 17-27.

Stuart, T.E., \& Ding, W.W. (2006). When do scientists become entrepreneurs? The social structural antecedents of commercial activity in the academic life sciences. American Journal of Sociology, 112(1), 97-144. 
Szpiro, G. (1986). Measuring risk aversion: An alternative approach. Review of Economics and Statistics, 68, 1156159.

Tang, J.K., Michele, K., \& Lowell, W.B. (2012). Entrepreneurial alertness in the pursuit of new opportunities. Journal of Business Venturing, 27(1), 77-94.

Tijssen, R.J.W. (2006). Universities and industrially relevant science: Toward measurement models and indicators of entrepreneurial orientation. Research Policy, 35(10), 1569-1585.

Torero, M., Darby, M.R., \&Zucker, L.G. (2001). The importance of intellectual human capital in the birth of the semiconductor industry. Working Paper: UCLA Anderson School, Los Angeles, CA.

Utsch, A., Rauch, A., Rothfuss, R., \&Frese, M. (1999). Who becomes a small scale entrepreneur in a post-socialist environment: On the differences between entrepreneurs and managers in East Germany. Journal of Small Business Management, 37(3), 31-41.

Uzzi, B. (1997). Social structure and competition in inter-firm networks: The paradox of embeddedness. Administrative Science Quarterly, 42, 33-67.

Venkataraman, S. (1997). The distinctive domain of entrepreneurship research: An editor's perspective. In Katz J and Brockhaus R. (eds.) Advances in entrepreneurship, firm emergence and growth, 3, 119-138. Greenwich, CT: JAI Press.

Westhead, P., Wright, M., \&McElwee, G. (2011) Entrepreneurship Prespectives and Cases. Gosport: Prentice Hall. Wright, M., Birley, S., \& Mosey, S. (2004). Entrepreneurship and university technology transfer. Journal of Technology Transfer, 29, 235-246.

Yildirim, N., \&Askun, O.B. (2012). Entrepreneurship Intentions of public universities in Turkey: Going beyond education and research.Procedia-Social and Behavioral Science, 58, 953-963.

Yusof, M., \& Jain, K.K. (2011). Entrepreneurial leadership and academic entrepreneurship in Malaysian public research universities. Bhavan's International Journal of Business, 5(2), 87-100.

Yusuf, N., \&Albanawi, N.I. (2016). The role of entrepreneurship in economic development in Saudi Arabia. Business and Economic Journal, 7(1).

Zucker, L.G., Darby, M.R., \& Brewer, M.B. (1998). Intellectual human capital and the birth of US Biotechnology enterprises. The American Economic Review, 88(1), 290-306.

Yildirim, N. \&Askun, O.B. (2012). Entrepreneurship intentions of public universities in Turkey going beyond education and research? Procedia - Social and Behavioral Sciences 58, 953-963

Nyeko, K.E \& Sing, N.K (2015). Academic entrepreneurs and entrepreneurial academics: Are they the same.International Journal of Social Science and Humanity, 5(12).

Ahmad, N.A., Halim, H.A., Ramayah, T. \& Rahman, S.A. (2013). Revealing an open secret: Internal challenges in creating an entrepreneurial university from the lens of the academics. International Journal of Conception on Management \& Social Science, 1(1), 2357-2787.

Sporn, B. (2001). Building adaptive universities: Emerging organizational forms based on experiences of European and US universities, Tertiary Education and Management,7(2), 121-134.

Radosevich, R. (1995). A model for entrepreneurial spin-offs from public technology sources, International Journal of Technology Management, 10, 879-893.

Tijssen, R.J. (2006). Universities and industrially relevant science: toward measurement models and indicators of entrepreneurial orientation, Research Policy, 35(10)1569-1585.

Binks, M., Starkey, K. \& Mahon, C. L. (2006). Entrepreneurship education and the business school. Technology Analysis \& Strategic Management, 18(1), 1-18.

Yusof, M., \& Jain, K.K. (2007). Categories of university-level entrepreneurship: A literature survey. The International Entrepreneurship and Management Journal, Online status, Springer Boston.

Sarkar, S (2014) International journal of finance and policy analysis.

London: Universal Publishers

Shane, Scott, \&Venkataraman, S (2000). The promise of entrepreneurship as a field entrepreneurship. Academy of Management Review, 25(1), 217-226.

Davidsson, P., \& Benson H. (2003). The role of social and human capital among nascent entrepreneurs. Journal of Business Venturing, 18(3), 301-331. 
Awolaja, A. M. (2020). Entrepreneurial Opportunity And Collaborative Research Efforts As Panaceas For Improving Academic Entrepreneurship Among Ekiti State University Staff. Archives of Business Research, 8(3), 42-52.

Owuala, S.I (1999). Entrepreneurship in small business firms, Lagos, GMAG Investment Ltd

Brennan, M.C., \& McGowan, P. (2006), Academic entrepreneurship: An exploratory case study, International Journal of Entrepreneurial Behaviour and Research,12(3), 144-164 